\title{
Seaward dipping reflectors along the SW continental margin of India: Evidence for volcanic passive margin
}

\author{
K K AjaY ${ }^{1, *}$, A K Chauber ${ }^{1, * *}$, K S Krishna ${ }^{1}$, D Gopala Rao ${ }^{2}$ and D SaR ${ }^{3}$ \\ ${ }^{1}$ National Institute of Oceanography (CSIR), Dona Paula, Goa 403 004, India. \\ ${ }^{2}$ Department of Geology, Osmania University, Hyderabad 500 007, India. \\ ${ }^{3}$ KDMIPE, Oil and Natural Gas Corporation, 9 Kaulagarh Road, Dehradun 248 195, India. \\ *Present address: Department of Geology, Government College Kottayam, Nattakom 686 013, Kerala, India. \\ **e-mail: chaubey@nio.org
}

Multi-channel seismic reflection profiles across the southwest continental margin of India (SWCMI) show presence of westerly dipping seismic reflectors beneath sedimentary strata along the western flank of the Laccadive Ridge - northernmost part of the Chagos-Laccadive Ridge system. Velocity structure, seismic character, 2D gravity model and geographic locations of the dipping reflectors suggest that these reflectors are volcanic in origin, which are interpreted as Seaward Dipping Reflectors (SDRs).

The SDRs; 15 to $27 \mathrm{~km}$ wide overlain by $\sim 1 \mathrm{~km}$ thick sediment; are observed at three locations and characterized by stack of laterally continuous, divergent and off-lapping reflectors. Occurrence of SDRs along western flank of the Laccadive Ridge adjacent to oceanic crust of the Arabian Basin and 2D crustal model deduced from free-air gravity anomaly suggest that they are genetically related to incipient volcanism during separation of Madagascar from India.

We suggest that (i) SWCMI is a volcanic passive margin developed during India-Madagascar breakup in the Late Cretaceous, and (ii) continent-ocean transition lies at western margin of the Laccadive Ridge, west of feather edge of the SDRs. Occurrence of SDRs on western flank of the Laccadive Ridge and inferred zone of transition from continent to ocean further suggest continental nature of crust of the Laccadive Ridge.

\section{Introduction}

The Western Continental Margin of India (WCMI) experienced multiple phases of extensional tectonics in the geological past. The margin has mainly evolved due to:

- rifting between Madagascar and India during the Late Cretaceous,

- short span of rifting between Seychelles-Laxmi Ridge and India around K-T boundary, and

- rifting between Seychelles and Laxmi Ridge during the Early Tertiary (Norton and Sclater 1979; Courtillot et al 1988; White and McKenzie 1989; Bhattacharya et al 1994; Storey 1995;
Storey et al 1995; Collier et al 2008; Minshul et al 2008).

Massive Deccan flood basalt erupted by the Réunion hotspot (68.5-62 Ma) was approximately time coincident with the last two phases of the rifting and had profound impact on the WCMI.

Rifting between southwestern India and the eastern Madagascar occurred during the Late Cretaceous and this event was associated with the Marion hotspot volcanism (White and McKenzie 1989; Storey et al 1995; Torsvik et al 1998; Raval and Veeraswamy 2003). The volcanic extrusion of this event was also recorded in the Cretaceous dolerite $(91.6 \pm 0.3 \mathrm{Ma})$ of Madagascar

Keywords. Southwest continental margin of India; Laccadive Ridge; seaward dipping reflectors; SDRs; gravity model; continent-ocean transition. 
and volcanics of St. Mary Islands $(85.6 \pm 0.9 \mathrm{Ma})$ off southwest India. Numerous basaltic flows and intrusives related to Marion hotspot volcanism are also reported from the southwest India (Radhakrishna et al 1994; Kumar et al 2001; Pande et al 2001).

The second major tectonic event contributed in shaping the western continental margin of India was the short span of rifting between SeychellesLaxmi Ridge and India. The Laxmi Basin evolved during this phase of rifting. It is not yet conclusively established whether this rift event had led to establishment of seafloor spreading in the Laxmi Basin. Therefore, nature of crust underneath the Laxmi Basin and the adjacent offshore Indus Basin is still being debated to be either oceanic or stretched continental crust (Naini and Talwani 1983; Miles et al 1998; Bhattacharya et al 1994; Talwani and Reif 1998; Todal and Eldholm 1998; Krishna et al 2006; Collier et al 2009; Yatheesh et al 2009).

Third major tectonic event which shaped the WCMI was separation of Seychelles from Laxmi Ridge-India during the Early Tertiary while the Réunion hotspot activity was in its peak phase. The Réunion hotspot related volcanism occurred initially on continental crust and later on oceanic crust as the Indian plate moved northwards over the hotspot. It created the Deccan Continental Flood Basalt province on the western and central India (Mahadevan 1994) as well as continental flood basalt on the Praslin Island on the Seychelles microcontinent (Devey and Stephens 1991). Further, it emplaced numerous magmatic intrusions/extrusions within the crust of western continental margin of India as the plate moved over it. Considerable stretching during rifting, and Réunion related massive volcanism, obliterated the pre-existing geology and initial margin configuration of southwest continental margin of India (SWCMI).

Though the WCMI is considered as a typical passive rifted margin (Biswas 1982; Chandrasekharam 1985), it is generally understood that southern margin of India is a non-volcanic passive margin evolved during breakup between southern India and eastern Madagascar. Whereas, northern continental margin of India is a volcanic passive margin developed during the breakup of India-Laxmi Ridge-Seychelles. This event of breakup was contemporaneous with predominant Deccan volcanic activity which produced widespread volcanism.

Despite the fact that the India-Madagascar breakup produced an extensive volcanic province along eastern Madagascar and numerous basaltic flows and intrusives on the southwest Indian shield, Seaward Dipping Reflectors (SDRs) - one of the most distinctive characteristic features of volcanic passive margins - are not yet reported from the SWCMI. The studies carried out so far on passive continental margins worldwide suggest that SDRs represent flood basalts rapidly extruded during either rifting or sub-aerial seafloor spreading. The seismic characters; continuity, dip, amplitude, reflection pattern and thickness of wedges of SDRs are controlled by:

- volume and rate of magma production,

- volcanic constructional environment (vent geometry, relation to sea level),

- syn- and post-volcanic deformation, and

- subsidence (Eldholm et al 1995).

SDRs are in general detectable in multi-channel seismic section as thick packets of high-amplitude reflections which are convex upward, offlapping seawards, divergent and laterally continuous. It may be mentioned here that wedges of SDRs are different from the normal faults developed during initial stage of continental rifting. These faults subsequently turn to half-graben structures, whose seismic signature differs from SDRs.

In this study we report, for the first time, occurrence of SDRs along the western flank of the Laccadive Ridge based on multi-channel seismic reflection data, and discuss its implications on the development of the margin.

\section{Physiographic and tectonic settings}

Physiographically, the SWCMI consists of narrow continental shelf, broad continental slope, Laccadive Basin, Laccadive Ridge and adjacent part of the Arabian Basin (figure 1). The continental crust of Dharwar craton extends in the western offshore up to Laccadive Ridge (Avasthi 2003). The Laccadive Basin, a narrow triangular shaped basin, is located between the Laccadive Ridge in the west and the southwestern continental slope of India in the east. The basin is divided into three sub-basins, at places, by the extruded structure of the Prathap Ridge and bathymetric high (shelfmargin high). The origin of the Prathap Ridge has been suggested as:

- a volcanic construct formed by the Réunion hotspot during northward movement of the Indian plate over the hotspot (Krishna et al 1992), and

- as a continental sliver, intermingled with dykes and volcanics, formed during rifting between India and Madagascar (Subrahmanyam et al 1995).

The NNW-trending Laccadive Ridge is the northernmost part of the Chagos-Laccadive 


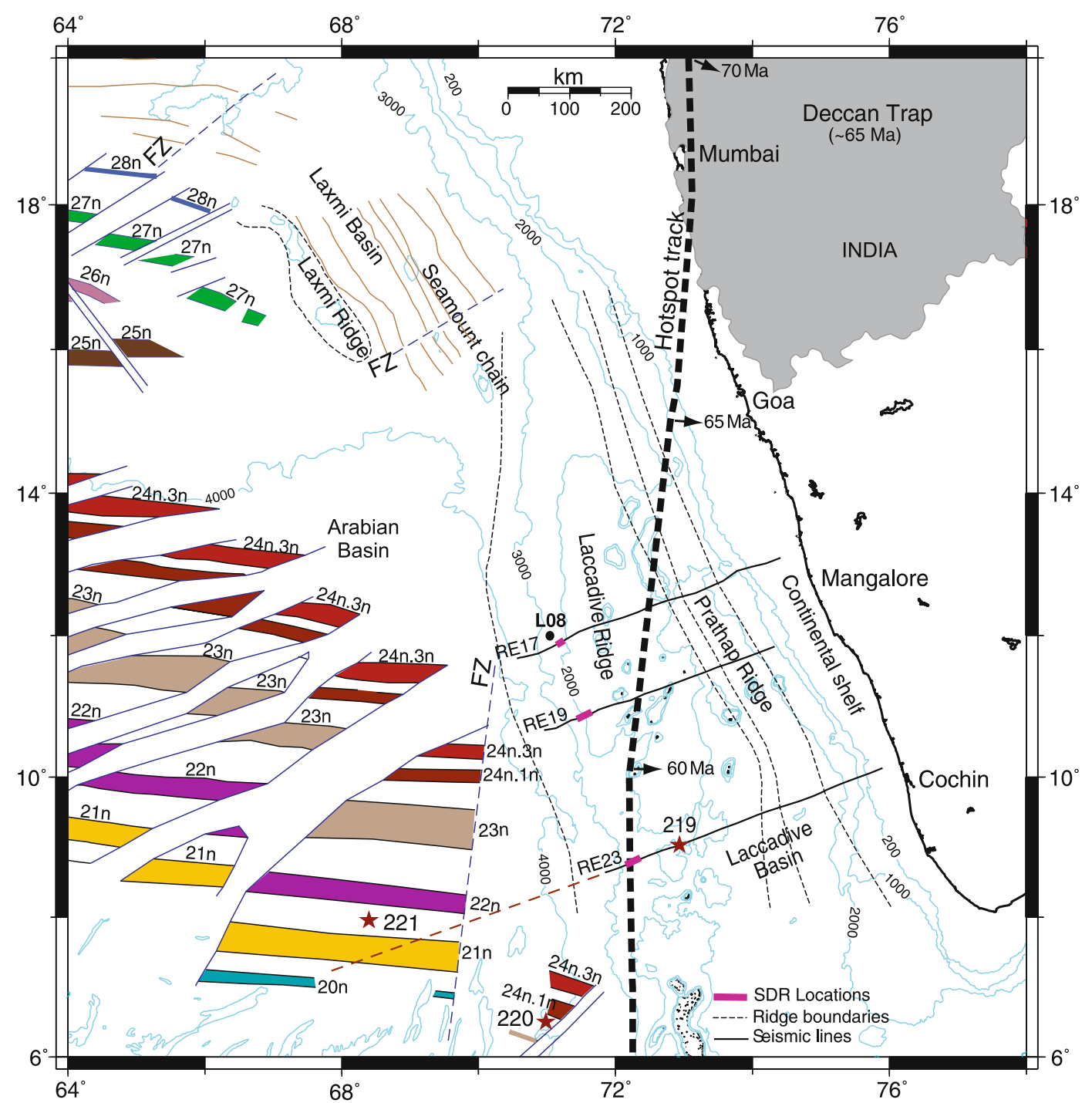

Figure 1. Generalized tectonic map of the western continental margin of India, showing annotated magnetic lineations, pseudofaults (thin blue lines), fracture zones (dashed blue lines annotated as FZ) (Chaubey et al 2002a) and boundaries of the Laccadive and Prathap ridges (thin dashed lines) (Naini and Talwani 1983). The locations of identified SDRs are marked on the seismic lines (thick red bar on RE lines); DSDP drill sites are shown with solid stars (Whitmarsh et al 1974); solid thick dashed line represents the computer-modeled Réunion hotspot track; numbers along the hotspot track are predicted ages in Ma (Shipboard Scientific Party 1988); magnetic lineations in the Laxmi Basin (thin brown lines) (Bhattacharya et al 1994; Malod et al 1997). 2D crustal model, shown in figure 5, was derived along line RE23. Extended (dashed line) portion of the line RE23 into the deep Arabian basin lacks multi-channel seismic reflection data.

Ridge (CLR) with an average width of $270 \mathrm{~km}$. The ridge is an elongated feature, lying roughly parallel to the west coast of India between latitudes $8^{\circ} \mathrm{N}$ and $16^{\circ} \mathrm{N}$ (Bhattacharya and Chaubey 2001; Chaubey et al 2008). The eastern and western limits of the ridge are bounded by fault scarps, which apparently separate the ridge from the Laccadive and Arabian basins, respectively (Avraham and Bunce 1977; Chaubey et al 2002b). The ridge is associated with relatively positive free-air gravity anomalies compared to the surrounding region and is characterized by thickened crust of high density $\left(3.0 \mathrm{~g} / \mathrm{cm}^{3}\right)$ material (Radha
Krishna et al 2002). Magnetic anomalies over the ridge do not show any definite pattern. The eastern part of the ridge is associated with subdued magnetic anomalies, whereas its western part is characterized by several prominent high magnetic anomalies (Naini and Talwani 1983; Gopala Rao et al 1987). The latter was interpreted as due to densely spaced igneous intrusives and flows (Chaubey et al 2002b). Even though, the nature of crust of the ridge is equivocal (Bhattacharya and Chaubey 2001 and references therein; Verzhbitsky 2003), the recent studies suggest that the ridge is comprised of thinned continental crust, which 

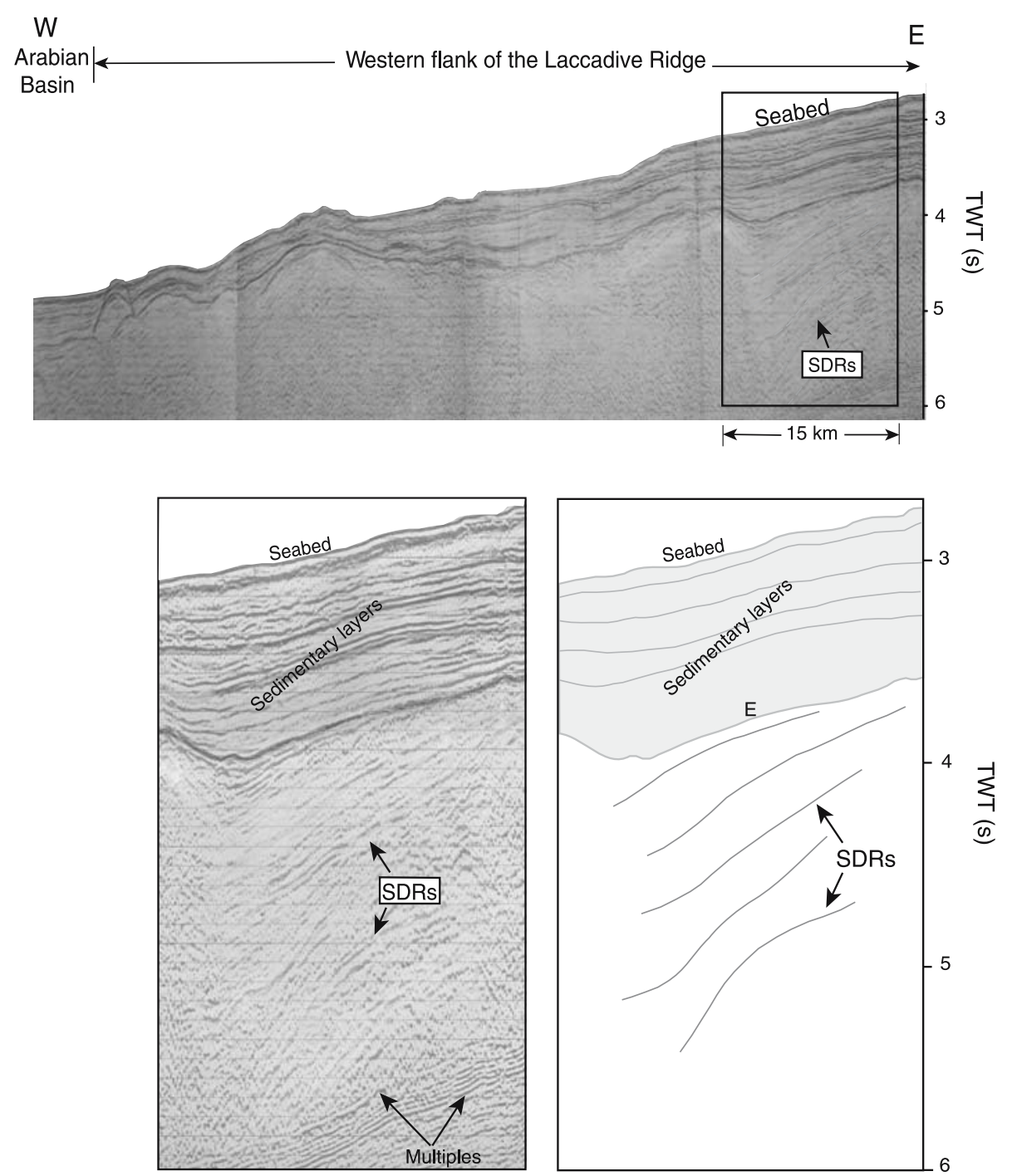

Figure 2. Multi-channel seismic section and interpreted line diagram along part of the line RE17 located on western flank of the Laccadive Ridge. SDRs are interpreted below sedimentary sequence.

was intruded-extruded by magmatic events during Madagascar-India continental rifting and passage of the Indian Plate over the Réunion hotspot (Murty et al 1999; Kothari et al 2001; Chaubey et al 2002a, 2008).

The Arabian Basin, conjugate to the eastern Somali Basin, is located west of the Laccadive Ridge. The basin is demarcated by the Owen fracture zone towards west and Carlsberg Ridge towards south. The northern and eastern limits of the basin is bounded by the aseismic Laxmi and Laccadive Ridges. The topography of the basin is determined by Indus fan sediments. The water depth varies from $3400 \mathrm{~m}$ in the north to about $4400 \mathrm{~m}$ in the south. The well developed Tertiary magnetic lineations established by various researchers indicate oceanic nature for the crust beneath the basin (Chaubey et al 1998, 2002b; Miles et al 1998; Dyment 1998; Royer et al 2002).

\section{Data}

We analyzed 2-D multi-channel seismic reflection profiles (figure 1) across SWCMI, under a collaborative project between National Institute of Oceanography (NIO) and Oil and Natural Gas Corporation (ONGC). The data were acquired in 100 to $4000 \mathrm{~m}$ water depth onboard $M / V$ Anweshak during December 1979 with 48-channel seismic streamer and Bolt type air gun array with a total capacity of 101 as a seismic source. A recording duration of $8 \mathrm{~s}$, a sampling interval of $4 \mathrm{~ms}$ and a shot interval of $50 \mathrm{~m}$ were chosen with a ship speed of 4-5 knots to achieve a 12 -fold coverage. The data were processed at the Computer Service Division of ONGC, Dehradun. We present part of the MCS section; located across the western flank of the Laccadive Ridge; of line RE17 (figure 2), RE19 (figure 3) and RE23 (figure 4) along with interpreted line drawings for analysis 

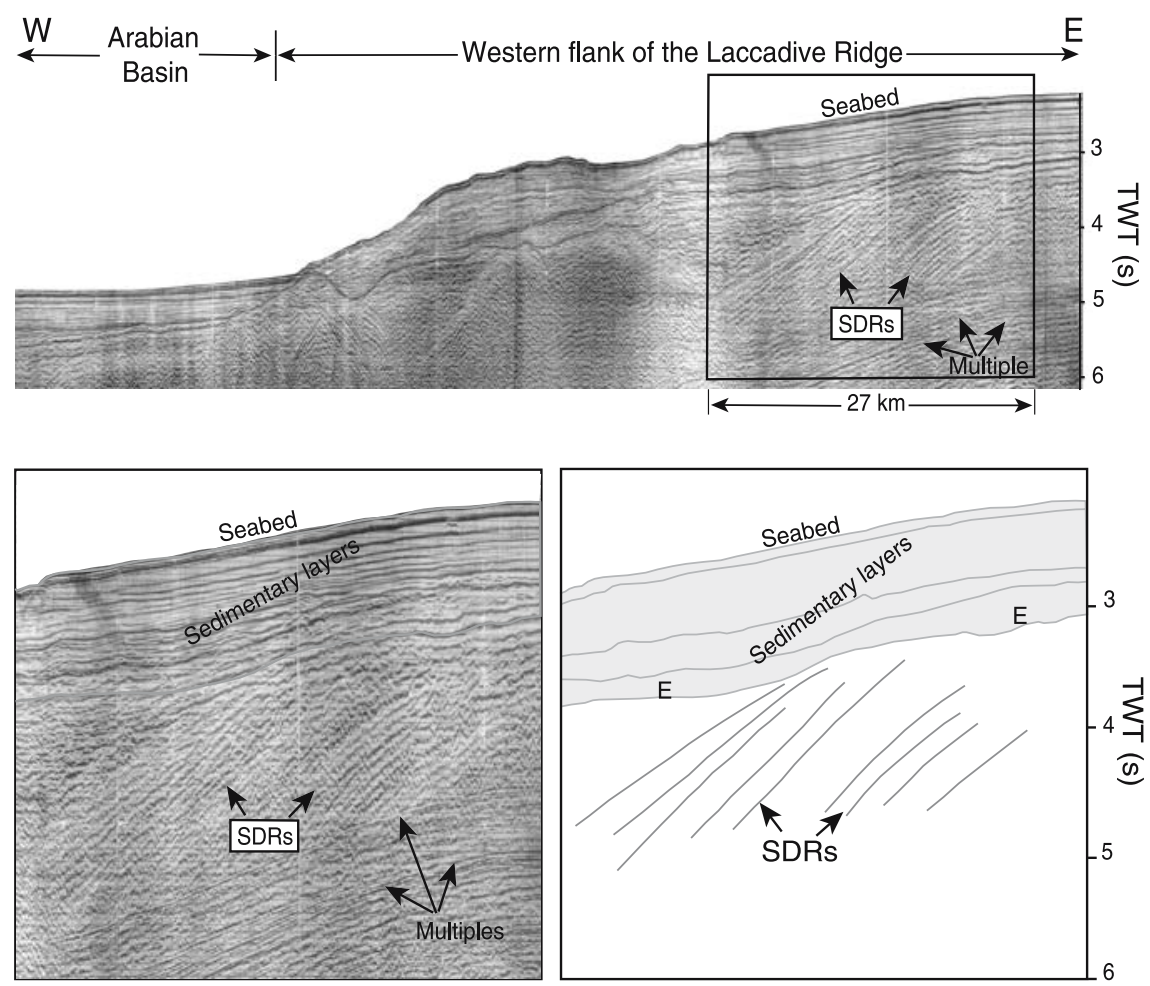

Figure 3. Multi-channel seismic section and interpreted line diagram along part of the line RE19 located on western flank of the Laccadive Ridge. SDRs are interpreted below sedimentary sequence.

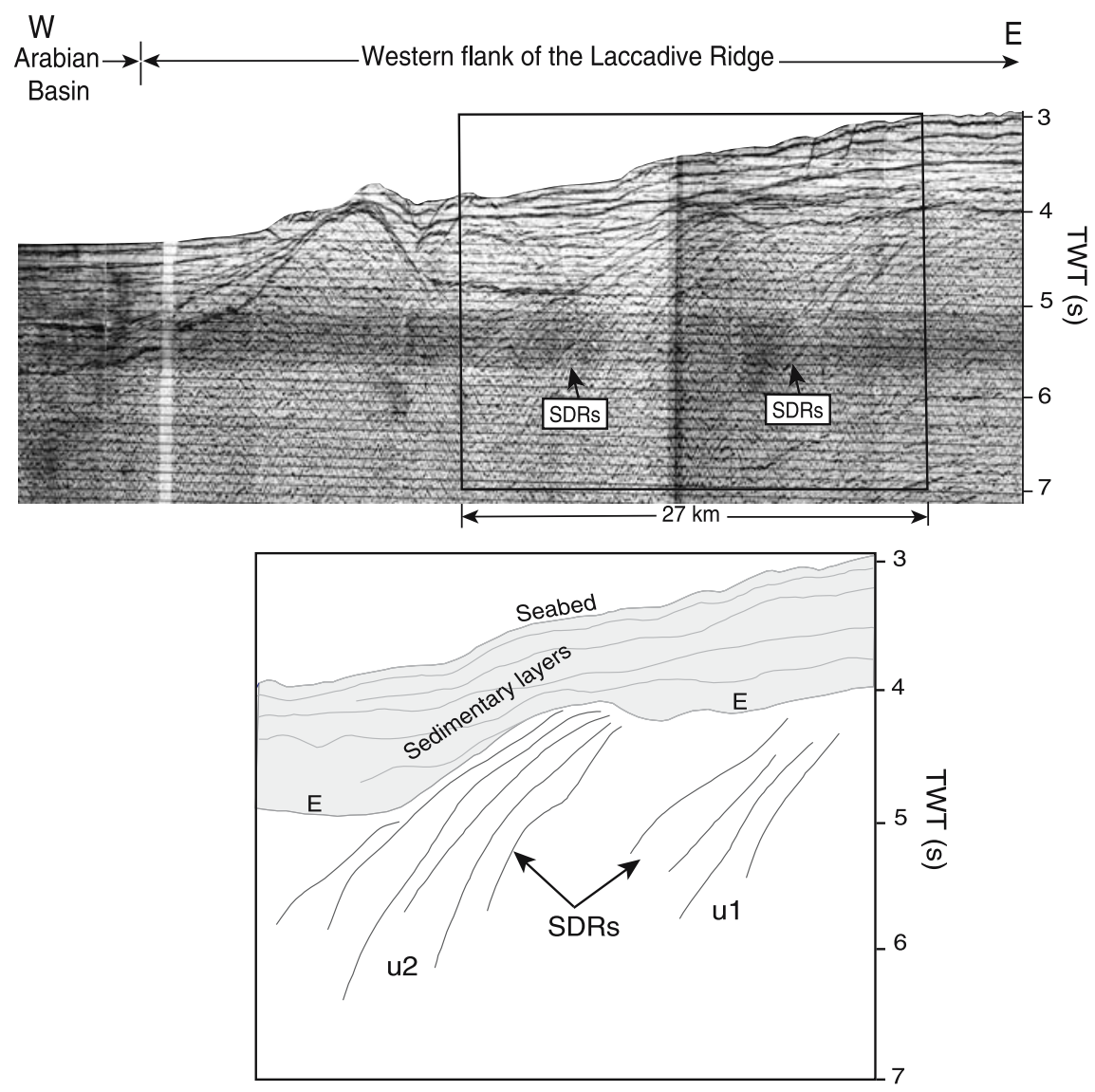

Figure 4. Multi-channel seismic section and interpreted line diagram along part of the line RE23 located on western flank of the Laccadive Ridge. SDRs are interpreted below sedimentary sequence. U1, U2 and reflector E are explained in the text. 
Table 1. Seismic velocity of crustal layers at refraction station L08 $\left(11.9067^{\circ} \mathrm{N}, 71.1750^{\circ} \mathrm{E}\right)$ located on western flank of the Laccadive Ridge.

\begin{tabular}{llllllll}
\hline Layer velocity $(\mathrm{km} / \mathrm{s})$ & 1.50 & 1.65 & 2.12 & 4.40 & 5.60 & 6.30 & 7.20 \\
Layer thickness $(\mathrm{km})$ & 2.12 & 0.41 & 0.42 & 0.66 & 1.49 & 4.69 & 8.40 \\
Layer thickness $\{(\mathrm{TWT}(\mathrm{s})\}$ & 2.83 & 0.50 & 0.40 & 0.30 & 0.53 & 1.49 & 2.33 \\
Cumulative layer thickness $\{(\mathrm{TWT}(\mathrm{s})\}$ & 2.83 & 3.33 & 3.73 & 4.03 & 4.56 & 6.05 & 8.38 \\
\hline
\end{tabular}

and interpretation. To support our interpretation, we utilize published results of seismic refraction (Naini and Talwani 1983) and DSDP Site 219 (Whitmarsh et al 1974). In addition, 2D gravity model studies were carried out along the profile RE23 under seismic constraints for determining crustal architecture across the SWCMI. Free-air gravity anomaly data along seismic line RE23 were retrieved from satellite altimetry derived grided gravity database of Sandwell and Smith (1997) as shipborne gravity data were not available along RE23.

\section{Analysis and interpretation}

The multi-channel seismic sections across the SWCMI have been compiled and analyzed in order to study igneous structures formed during initial stage of continental breakup. We found interesting dipping seismic reflectors beneath sedimentary strata along western flank of the Laccadive Ridge. These reflectors are interpreted as SDRs which provide sufficient condition for classifying SWCMI as a volcanic passive margin.

\subsection{Characteristics of SDRs}

The dipping seismic reflectors observed below sedimentary strata along the western flank of the Laccadive Ridge are discontinuous to continuous, high amplitude, divergent and westerly dipping (figures 2, 3 and 4). Along line RE17 (figure 2), the westerly dipping reflectors are overlain by $\sim 0.95 \mathrm{~s}$ TWT thick sediments. Individual reflectors can be traced for up to $\sim 15 \mathrm{~km}$ down dip and the depth to the highest distinguishable point of top layer of the reflectors is $\sim 3.8 \mathrm{~s}$ TWT. Along line RE19, well developed dipping reflectors are overlain by $\sim 1.2 \mathrm{~s}$ TWT thick sediments and extend seaward for $\sim 27 \mathrm{~km}$ (figure 3 ). The top of the dipping reflectors lies at a depth of $\sim 3.6 \mathrm{~s}$ TWT. Figure 4 depicts two sets of westerly dipping reflector sequences ( $u 1$ and u2) along line RE23. The reflector sequences, separated by $\sim 5 \mathrm{~km}$ apart, are overlain by $\sim 0.9 \mathrm{~s}$ TWT thick sediments and extend seaward for $\sim 27 \mathrm{~km}$. The depth to the top of the dipping reflectors is $\sim 4.2 \mathrm{~s}$ TWT. It may be noted that the dipping reflectors are convex upward, offlapping seawards, divergent and laterally continuous.

In order to investigate the nature of the dipping seismic reflectors, we used published results of DSDP Site 219 (Whitmarsh et al 1974) and refraction study at site L08 (Naini and Talwani 1983) located on the crest and western flank of the Laccadive Ridge, respectively. The velocity structure at site L08 (table 1) which is close to the dipping seismic reflectors observed at line RE17 consists of crustal layers of P-wave velocities 1.65-2.12, 4.4, $5.6,6.3$ and $7.2 \mathrm{~km} / \mathrm{s}$. The presence of chert layer of P-wave velocity $4.0 \mathrm{~km} / \mathrm{s}$ of Early and Middle Eocene age overlain by $\sim 1 \mathrm{~km}$ thick sediment over the Laccadive Ridge was inferred at DSDP Site 219. The chert layer appears as a strong diffuse reflector with irregular surface often with sawtooth appearance (Whitmarsh et al 1974). Chaubey et al (2002b) observed that reflection character of chert layer is of high-amplitude, and discontinuously associated with numerous diffraction hyperbolae. Such reflection character at bottom of the sedimentary strata (figures 2-4) is not observed in the study area. Instead, it displays high amplitude and continuous reflector named as ' $\mathrm{E}$ '. Below the reflector ' $\mathrm{E}$ ', we observed discontinuous to continuous, high amplitude, divergent and westerly dipping offlapping reflectors (figures 2-4).

The velocities in the range $5.8-6.4 \mathrm{~km} / \mathrm{s}$ are generally considered as characteristic of granitic layer in continental crust (Tucholke et al 1981). From a compilation of global crustal model, Mooney et al (1998) suggested $6.1-6.3 \mathrm{~km} / \mathrm{s}$ velocity to upper-middle crustal layer of extended continental crust. We, therefore, assign seismic velocity of the dipping reflectors as $\geq 4.4 \mathrm{~km} / \mathrm{s}$ (table 1). Deep seismic sounding investigations of the western Indian shield suggested that seismic velocity of Deccan flow basalt, lie below thick sediment column, vary between 4.7 and $5.1 \mathrm{~km} / \mathrm{s}$ (Kaila et al 1981a, 1981b; Reddy 2005). From the study of dipping reflector sequence on Hatton Bank, White et al (1987) suggested that the seismic velocities increase through the SDRs from typically $3.5 \mathrm{~km} / \mathrm{s}$ at the top to about $6 \mathrm{~km} / \mathrm{s}$ at the base. We therefore suggest that the seismic reflectors are dipping volcanic reflectors with seismic velocity $\geq 4.4 \mathrm{~km} / \mathrm{s}$. Considering the geographic location and seismic characters of dipping 
volcanic reflectors, we interpret them as SDRs and not as dipping normal faults because the latter do not show associated half-graben structures which are formed during initial stage of continental rifting. Further, in the locations where the SDRs are interpreted; the sub-surface is clearly devoid of normal fault characteristics. In view of the above, we believe that the dipping volcanic reflectors identified on the western flank of the Laccadive Ridge are well developed SDRs. We consider that the dips of the SDRs arose from basaltic lava flows emplaced during initial continental split-up and subsequent subsidence. According to Hinz (1981) and Mutter et al (1982) the regions of SDRs generally mark areas of rifted continent and their dips arose from the subsidence of enormous volumes of basaltic lava flows. Feather edge of the SDRs have been used to demarcate seaward extent of the continental crust of the Voring Plateau of Norwegian margin, Argentina margin and east coast of US (Baltimore Canyon Trough and Carolina Trough) (White et al 1987). We interpret the identified SDRs on western flank of the Laccadive Ridge are indicative of rifted continents and volcanism prior to onset of seafloor spreading. The presence of SDRs and their feather edge along the western flank of the Laccadive Ridge lead us to identify the edge of the rifted continent, and thereby to demarcate the region of continent-ocean transition along the western margin of the ridge.

\subsection{Crustal architecture from $2 D$ gravity model}

Satellite altimetry derived free-air gravity anomaly data are used to derive crustal model along seismic line RE23 which traverses across the southwest continental margin of India. We extended line RE23 into the deep Arabian Basin, although not covered by the MCS data, for the purpose of crustal modelling from known oceanic crust of the basin to continental shelf. 2D gravity modelling was carried out using the GM-SYS software. As a first step, main crustal layers are identified and thickness of each crustal layers are computed based on the MCS time section, MCS derived average seismic velocity in the sedimentary strata and published refraction results (Naini and Talwani 1983) of the study area. The depth-converted horizons were incorporated into the simplified crustal model in order to obtain initial crustal configuration for forward gravity modelling. Bathymetry, sediment thickness and igneous crustal layers were extracted from the public domain data (NGDC, National Geophysical Data Center, USA) and the published refraction results. Deep seismic sounding results from western Indian shield (Kaila et al 1981a; Reddy 2005) are used to estimate the Moho depth on the continental shelf region. Densities for various crustal layers are obtained from velocitydensity conversion table of Barton (1986), which provides a range of densities for a seismic velocity of a rock formation. Since density-velocity relation is non-linear, it possesses limitations on the direct use of density obtained from an assumed linear density-velocity relationship. Therefore, we selected mean density within the given range of densities for a particular seismic velocity (Barton 1986). Modelling was performed by continuously applying small adjustments to the geometries of crustal layers in order to obtain a crustal model which satisfies both the geometrical constraints and an acceptable fit between observed and calculated gravity anomalies.

The investigations along Kavali-Udipi profile in the south, and Koyna-I and Koyna-II profiles in the north revealed that the $\mathrm{P}$-wave velocities vary between (i) 4.7 and $5.0 \mathrm{~km} / \mathrm{s}$ in Deccan Traps; (ii) 5.5 and $5.8 \mathrm{~km} / \mathrm{s}$ in Cuddapah sediments and Dharwar schists, and (iii) 5.8 and $6.2 \mathrm{~km} / \mathrm{s}$ in granites and granitic gneisses (Kaila et al 1979, 1981a, 1981b). The refraction velocities data; compiled from the SWCMI; comprise of $1.7-2.1 \mathrm{~km} / \mathrm{s}$, $4.2-4.4,5.4-5.7,6.1-6.4$ and $7.2-7.3 \mathrm{~km} / \mathrm{s}$. The seismic velocities $1.7-2.1 \mathrm{~km} / \mathrm{s}$ represent sedimentary column, whereas $4.2-4.4 \mathrm{~km} / \mathrm{s}$ represent basaltic flows. The rocks with velocities of $5.4-5.7 \mathrm{~km} / \mathrm{s}$ and $6.1-6.4 \mathrm{~km} / \mathrm{s}$ below sedimentary strata are similar to the velocities observed in Dharwar schists/Cuddapah sediments and granitic gneisses, respectively. The velocities $7.2-7.3 \mathrm{~km} / \mathrm{s}$ may represent lower continental crust. It may be noted that the inferred granitic crustal velocities 6.1 to $6.4 \mathrm{~km} / \mathrm{s}$ are slightly higher compared to that of DSS results. The high velocity may indicate altered granitic layer due to intrusive volcanism during rift related extensional tectonics and/or hotspot magmatism. The seismic velocities of the crustal layers have been converted into densities as described above.

The best-fit crustal model (figure 5) revealed 22, 19 and $6 \mathrm{~km}$ thick crusts of the outer shelf, Laccadive Ridge and Arabian Basin, respectively. The crustal densities of the Arabian Basin consist of three layers of $2.1,2.7$ and $2.95 \mathrm{~g} / \mathrm{cm}^{3}$ representing sediments, layers 2 and 3 of the oceanic crust respectively, whereas the crustal densities of the continental shelf, Laccadive Basin and the Laccadive Ridge consist of 2.1, 2.8, 2.9 and $3.0 \mathrm{~g} / \mathrm{cm}^{3}$, representing sediments, upper and lower stretched continental crust, and lower crustal body, respectively. A thick layer of meta sediment of density $2.65 \mathrm{~g} / \mathrm{cm}^{3}$ is inferred below basaltic flows. Densities ranging from $2.4-2.65 \mathrm{~g} / \mathrm{cm}^{3}$ are of igneous intrusive bodies, SDRs and chert layer. A lower crustal body, characterized by high density 


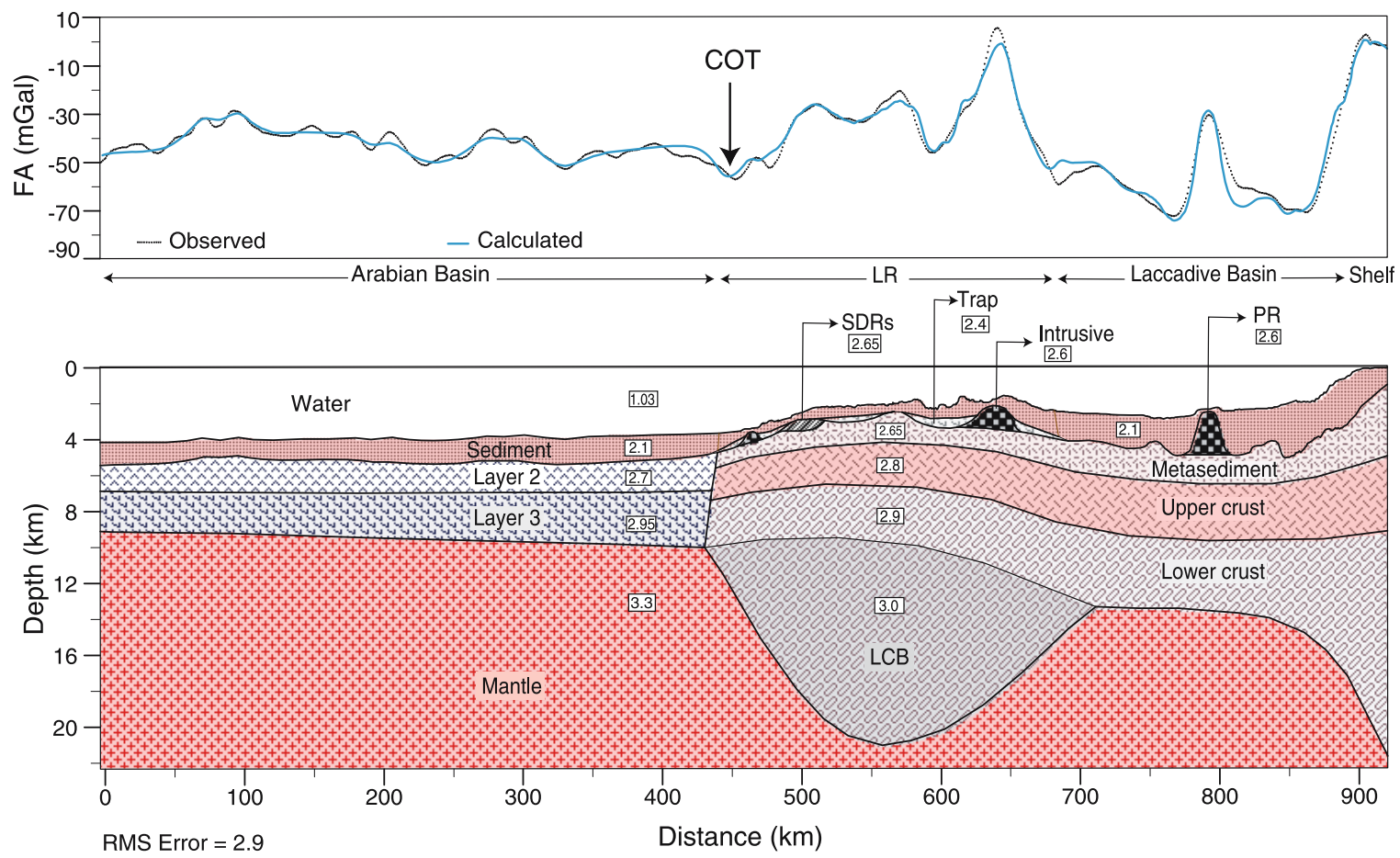

Figure 5. 2D crustal model based on gravity anomaly across the southwest continental margin of India along line RE23. Structure of volcanic intrusives and the Prathap Ridge (PR) are shown only in sedimentary and water columns as there are no appreciable lateral density contrast between adjoining horizons and the structure underlying the sedimentary strata. High density $\left(3.0 \mathrm{~g} / \mathrm{cm}^{3}\right.$ ) Lower Crustal Body (LCB) of the Laccadive Ridge may represent stretched crust associated with injection of dykes and sills. Inferred continent-ocean transition (COT) at feather end of the SDRs is indicated. Annotated values in rectangular boxes refer to inferred densities in $\mathrm{g} / \mathrm{cm}^{3}$.

$\left(3.0 \mathrm{~g} / \mathrm{cm}^{3}\right)$ material, is inferred below Laccadive Ridge. It may be noted that structure of volcanic intrusives and the Prathap Ridge (PR) are shown only in sediment and water columns as there are no appreciable lateral density contrast between adjoining horizons and the structure, underlying the sedimentary strata.

\section{Tectonic implication}

One of the most important results of the present study is seismically imaged strong SDR sequences along the western flank of the Laccadive Ridge (figure 1). They have been identified below sedimentary strata at three locations (figures 1-4). Seaward of their occurrences, the Laccadive Ridge gradually thins towards offshore and juxtaposed with Early Tertiary normal oceanic crust $(\sim 6 \mathrm{~km}$ thick) of the Arabian Basin. We infer that these wedges have been emplaced under subaquatic conditions due to progressive subsidence of the volcanic-magmatic crust. It may be noted that DSDP Site 219, drilled at the crest of the Laccadive Ridge $\left(9.02917^{\circ} \mathrm{N}, 72.87783^{\circ} \mathrm{E}\right)$, bottomed in Upper Paleocene sediments having an approximate age of $\sim 58 \mathrm{~m} . y$. The oldest sediment (limestone, sandstone and silt) strongly reflect typical shelf type nearshore shallow water sedimentation. These results led Weser (1974) to suggest that Site 219 was much closer to shoreline of India than it is today. Though, the identified SDRs are away from Site 219, it may be interpreted that (i) the SDRs are older than 58 m.y. as they are found below the sedimentary column, and (ii) the SDRs are emplaced under sub-aerial condition.

In paleo-geographic reconstructions, it is presumed that the southwest India rifted from the eastern margin of Madagascar during the Late Cretaceous (White and McKenzie 1989; Storey et al 1995, 1997; Torsvik et al 1998; Raval and Veeraswamy 2003). The rifting process was associated with the Marion hotspot volcanism which occurred at Volcan de l'Androy, southeast Madagascar and caused the eruption of widespread basalts and rhyolites in Madagascar and Fe-Tienriched tholeiites in southwest India. In light of the results of the present study we believe that eastern Madagascar rifted from the Laccadive Ridge which was part of Indian mainland. Based on admittance analysis of gravity and bathymetry data, Chaubey et al (2008) suggested that the Laccadive Ridge comprises thinned continental crust that is locally compensated by the Airy model of isostasy. Their inferences were further supported by comparable velocity and inferred crustal 
structure of the Laccadive Ridge with that of the Laxmi Ridge, which has been widely accepted as a continental sliver (Miles and Roest 1993; Bhattacharya et al 1994; Miles et al 1998; Talwani and Reif 1998; Todal and Eldholm 1998; Radha Krishna et al 2002).

It is quite likely that the Marion hotspot might have played a limited role at the SWCMI unlike the widespread volcanism by Réunion hotspot in the north (Dev et al 2007). The crustal structure derived from modelling of free-air gravity anomalies in the present study reveals high density lower crustal body below the Laccadive Ridge, which is consistent with the crustal model suggested by Radha Krishna et al (2002). The geophysical expression of the high-density lower crust is complex. Such lower crustal bodies may be interpreted as either a magmatic structure or a stretched crust associated with injection of dykes and sills. The presence of thick highdensity lower crustal body below the Laccadive Ridge can be interpreted due to massive intrusions by the Marion hotspot during initial stage of rifting between Madagascar and LaccadiveIndia, and later by the Réunion hotspot when the Indian Plate moved over it during northward motion.

The results of present study warrant a fresh look of multi-channel seismic reflection, Ocean Bottom Seismometer (OBS) derived refraction, gravity and magnetic data in order to address Late Cretaceous continental breakup between Madagascar and Laccadive-India. It may be noted that volcanic rifted margin segment may be predominantly volcanic without SDRs being imaged in seismic records. Therefore, SDRs are a sufficient, but not necessary condition for volcanic margin classification (Eldholm et al 1995). SDRs of the present study, indeed, suggest that SWCMI is a volcanic passive margin developed during breakup between Madagascar and Laccadive-India in the Late Cretaceous.

\section{Conclusions}

Study of multi-channel seismic reflection and freeair gravity anomaly profiles provided important constraints on early tectonic development of the SWCMI. We identified and interpreted, for the first time, the SDRs on the SWCMI. The crustal architecture derived from gravity model across the margin highlights large variation in crustal configuration and presence of lower crustal body of density $3.0 \mathrm{~g} / \mathrm{cm}^{3}$ below the Laccadive Ridge. We infer that SWCMI is a volcanic passive margin developed during breakup between India and Madagascar in the Late Cretaceous based on occurrences of extrusive volcanism (SDRs), intrusive magmatism and lower crustal body associated with injection of dykes and sills. We also infer that the Laccadive Ridge is a thinned continental crust and the continental-ocean boundary lie on western margin of the ridge, west of the inferred SDRs.

\section{Acknowledgements}

This work was carried out under a collaborative project between NIO and ONGC. We are thankful to Dr Satish R Shetye, Director, NIO, and the Executive Director, KDMIPE, ONGC for the encouragement and support in the joint research work. KKA thanks the Council of Scientific and Industrial Research, New Delhi, for financial assistance in the form of Senior Research Fellowship. This work was carried out under the project MoES/P.O.(Seismo)/23(645)/2007 of the Ministry of Earth Sciences, New Delhi. This is NIO contribution number 4812.

\section{References}

Avasthi D N 2003 Some issues related to the study of the Indian lithosphere; Geol. Soc. India Memoir $\mathbf{5 3}$ 313-346.

Avraham Z B and Bunce E T 1977 Geophysical study of the Chagos-Laccadive Ridge, Indian Ocean; J. Geophys. Res. 82 1295-1305.

Barton P J 1986 The relationship between seismic velocity and density in the continental crust - a useful constraint?; Geophys. J. R. Astr. Soc. London 87 195-208.

Bhattacharya G C, Chaubey A K, Murty G P S, Srinivas K, Sarma K V L N S, Subrahmanyam V and Krishna K S 1994 Evidence for seafloor spreading in the Laxmi Basin, northeastern Arabian Sea; Earth Planet. Sci. Lett. 125 $211-220$

Bhattacharya G C and Chaubey A K 2001 Western Indian ocean - A glimpse of the Tectonic Scenario; In: The Indian Ocean - A perspective (eds) Sen Gupta $\mathrm{R}$ and Desa E; pp. 691-729. Oxford-IBH, New Delhi.

Biswas S K 1982 Rift basins in the western margin of India and their hydrocarbon prospects; Bull. Am. Assoc. Petrol. Geol. 66 1497-1513.

Chandrasekharam D 1985 Structure and evolution of the western continental margin of India deduced from gravity, seismic, geomagnetic and geochronological studies; Phys. Earth Planet. Int. 41 186-198.

Chaubey A K, Bhattacharya G C, Murty G P S, Srinivas K, Ramprasad T and Gopala Rao D 1998 Early Tertiary seafloor spreading magnetic anomalies and paleo-propagators in the northern Arabian Sea; Earth Planet. Sci. Lett. 154 41-52.

Chaubey A K, Dyment J, Bhattacharya G C, Royer J Y, Srinivas K and Yatheesh V 2002a Paleogene magnetic isochrons and paleo-propagators in the Arabian and Eastern Somali basins, northwest Indian Ocean; In: The Tectonic and Climatic Evolution of the Arabian Sea Region (eds) Clift P D, Kroon D, Gaedicke C and Craig J; Geol. Soc. London Spec. Publ. 195 $71-85$. 
Chaubey A K, Gopala Rao D, Srinivas K, Ramprasad T, Ramana M V and Subrahmanyam V 2002b Analyses of multichannel seismic reflection, gravity and magnetic data along a regional profile across the central-western continental margin of India; Mar. Geol. 182 303-323.

Chaubey A K, Srinivas K, Ashalathab B and Gopala Rao D 2008 Isostatic response of the Laccadive Ridge from admittance analysis of gravity and bathymetry data; J. Geodynamics 46 10-20.

Collier J S, Sansom V, Ishizuka O, Taylor R N, Minshull T A and Whitmarsh R B 2008 Age of Seychelles-India break-up; Earth Planet. Sci. Lett. 272 264-277.

Collier J S, Minshull T A, Hammond J O S, Whitmarsh R B, Kendall J M, Sansom V, Lane C I and Rumpker G 2009 Factors influencing magmatism during continental break up: New insights from a wide-angle seismic experiment across the conjugate Seychelles-Indian margins; J. Geophys. Res. 114 B03101, doi:10.1029/2008JB005898.

Courtillot V, Feraud G, Maluski H, Vandamme D, Moreau M G and Besse J 1988 Deccan flood basalts and the Cretaceous/Tertiary boundary; Nature $\mathbf{3 3 3}$ 843-846.

Dev S V, Radhakrishna M and Subrahmanyam C 2007 Estimates of elastic thickness along the southwest continental margin of India using coherence analysis of gravity and bathymetry data - geodynamic implications; J. Geol. Soc. India $70475-487$.

Devey C W and Stephens W E 1991 Tholeiitic dykes in the Seychelles and the original spatial extent of the Deccan; J. Geol. Soc. London 148 979-983.

Dyment J 1998 Evolution of the Carlsberg Ridge between 60 and $45 \mathrm{Ma}$ : Ridge propagation, spreading asymmetry, and the Deccan-Réunion hotspot; J. Geophys. Res. 103 $24,067-24,084$.

Eldholm O, Skogseid J, Planke S and Gladczenko T P 1995 Volcanic margin concepts; In: Rifted Ocean-Continent Boundaries (eds) Banda E, Torné $\mathrm{M}$ and Talwani M (London: Kluwer Academic Publ.) pp. 1-16.

Gopala Rao D, Bhattacharaya G C, Subba Raju L V, Ramana M V, Subrahmanyam V, Raju K A K, Ram Prasad T and Chaubey A K 1987 Regional marine geophysical studies of the south western continental margin of India; In: Contributions in marine sciences (eds) Rao T S S, Natarajan R, Desai B N, Swamy G N and Bhat S R; NIO, Goa, pp. 427-437.

Hinz K 1981 A hypothesis on terrestrial catastrophes: Wedges of very thick ocean ward-dipping layers beneath passive ciontinental margins - Their origin and paleoenvironmental significance; Geol. Jahrb. Ser. E 22 3-28.

Kaila K L, Reddy P R, Krishna V G, Roy Chowdhury K, Tewari H C, Murty P R K and Tripathi K M 1979 Crustal investigations in India from deep seismic soundings; Geophys. Res. Bull. 17 273-292.

Kaila K L, Reddy P R and Dixit M M 1981a Deep crustal structure at Koyna, Maharashtra, indicated by deep seismic soundings; J. Geol. Soc. India 22 1-16.

Kaila K L, Murty P R K, Rao V K and Kharetcheko G E 1981b Crustal structure from deep seismic sounding along the Koyna II (Kelsi-Loni) profile in the Deccan Trap area, India; Tectonophys. 73 365-384.

Kothari V, Waraich R S, Dirghangi R S, Baruah R M, Lal N K and Zutshi P L 2001 A reassessment of the hydrocarbon prospectivity of Kerala - Konkan deep water basin, western offshore, India; In: Hydrocarbon Exploration (ed.) Bhatnagar A K; Proc. Fifth Int. Pet. Conf. $\& 3$ Exbn, Petrotech-2001.

Krishna K S, Murty G P S, Srinivas K and Gopala Rao D 1992 Magnetic studies over the northern extension of the
Prathap Ridge complex, eastern Arabian Sea; Geo-Mar. Lett. 12 7-13.

Krishna K S, Gopala Rao D and Sar D 2006 Nature of the crust in the Laxmi Basin $\left(14^{\circ}-20^{\circ} \mathrm{N}\right)$, western continental margin of India; Tectonics TC1006, doi:10.1029/2004TC001747.

Kumar A, Pande K, Venkatesan T R and Baskar Rao Y J 2001 The Karnataka Late Cretaceous dykes as products of the Marion hot spot at the Madagascar-India breakup event: Evidence from ${ }^{40} \mathrm{Ar}-{ }^{39} \mathrm{Ar}$ geochronology and geochemistry; Geophys. Res. Lett. 28 2715-2718.

Mahadevan T M 1994 Deep Continental Structure of India: A Review; Geol. Soc. India Memoir 28569 pp.

Malod J A, Droz L, Mustafa Kamal B and Patriat P 1997 Early spreading and continental to oceanic basement transition beneath the Indus-deep sea fan: Northeastern Arabian Sea; Mar. Geol. 141 221-235.

Miles P R and Roest W R 1993 Earliest sea-floor spreading magnetic anomalies in the north Arabian Sea and the ocean-continent transition; Geophys. J. Int. 115 $1025-1031$.

Miles P R, Munschy M and Segoufin J 1998 Structure and early evolution of the Arabian Sea and East Somali Basin; Geophys. J. Int. 134 876-888.

Minshull T A, Lane C I, Collier J S and Whitmarsh R B 2008 The relationship between rifting and magmatism in the northeastern Arabian Sea; Nature Geoscience 1 463-467.

Mooney W D, Laske G and Masters T G 1998 CRUST 5.1: A global crustal model at $5^{\circ} \times 5^{\circ} ; J$. Geophys. Res. 103 727-747.

Murty A V S, Arasu R T, Dhanawat B S and Subrahmanyam V S R 1999 Some aspects of deepwater exploration in the light of new evidences in the western Indian offshore; In: Petrotech-99, Hydrocarbon Exploration - Vol IV (ed.) Bhatnagar A K (Faridabad, India: Thomson Press) pp. 457-463.

Mutter J, Talwani M and Stoffa P L 1982 Origin of seawarddipping reflectors in oceanic crust off the Norwegian margin by 'subaerial sea-floor spreading'; Geology $\mathbf{1 0}$ 353-357.

Naini B R and Talwani M 1983 Structural framework and the evolutionary history of the continental margin of western India; In: Studies in Continental Margin Geology (eds) J S Watkins and C L Drake; Am. Assoc. Pet. Geol. Mem. 34 167-191.

Norton I O and Sclater J G 1979 A model for the evolution of the Indian Ocean and the breakup of the Gondwanaland; J. Geophys. Res. 84 6803-6830.

Pande K, Sheth H C and Bhutani R 2001 Ar40-Ar39 age of the St. Mary's Islands Volcanics, Southern India: Record of India-Madagascar break-up on the Indian subcontinent; Earth Planet. Sci. Lett. 193 39-46.

Radha Krishna M, Verma R K and Purushotham A K 2002 Lithospheric structure below the eastern Arabian Sea and adjoining west coast of India based on integrated analysis of gravity and seismic data; Mar. Geophys. Res. 23 $25-42$.

Radhakrishna T, Dallmeyer R D and Joseph M 1994 Paleomagnetism and ${ }^{36} \mathrm{Ar} /{ }^{40} \mathrm{Ar}$ vs. ${ }^{39} \mathrm{Ar} /{ }^{40} \mathrm{Ar}$ isotope correlation ages of dyke swarms in central Kerala, India: Tectonic implications; Earth Planet. Sci. Lett. 121 $213-226$.

Raval U and Veeraswamy K 2003 India-Madagascar separation: Breakup along a pre-existing mobile belt and chipping of the craton; Gondwana Res. 6 467-485.

Reddy P R 2005 Crustal velocity structure of western India and its use in understanding intraplate seismicity; Curr. Sci. 88 1652-1657. 
Royer J Y, Chaubey A K, Dyment J, Bhattacharya G C, Srinivas K, Yatheesh V and Ramprasad T 2002 Paleogene plate tectonic evolution of the Arabian and Eastern Somali basins; In: The Tectonic and Climatic Evolution of the Arabian Sea Region (eds) Clift P D, Kroon D, Gaedicke C and Craig J; Geol. Soc. London Spec. Publ. 195 7-23.

Sandwell D T and Smith W H F 1997 Marine gravity anomaly from Geosat and ERS 1 satellite altimetry; J. Geophys. Res. 102 10,039-10,054.

Shipboard Scientific Party 1988 Site 715. In: Proceedings of the Ocean Drilling Program - Initial Reports (eds) Backman J and Duncan R A et al; 115 917-946. Collge Station, TX.

Storey B C 1995 The role of mantle plumes in continental breakup: Case histories from Gondwanaland; Nature $\mathbf{3 7 7}$ 301-308.

Storey M, Mahoney J J, Saunders A D, Duncan R A, Kelley S P and Coffin M F 1995 Timing of hot spotrelated volcanism and the breakup of Madagascar and India; Science 267 852-855.

Storey M, Mahoney J J and Saunders A D 1997 Cretaceous basalts in Madagascar and the transition between plume and continental lithosphere mantle sources; In: Large Igneous provinces: Continental, Oceanic, and Planetary Flood Volcanism (eds) Mahoney J J and Coffin M; Am. Geophys. Union, Monogr, Washington, DC, pp. 95-122.

Subrahmanyam V, Gopala Rao D, Ramana M V, Krishna K S, Murty G P S and Rao M G 1995 Structure and tectonics of the southwestern continental margin of India; Tectonophys. 249 267-282.

Talwani M and Reif C 1998 Laxmi Ridge - A continental sliver in the Arabian Sea; Mar. Geophys. Res. 20 259-271.
Todal A and Eldholm O 1998 Continental margin off western India and Deccan Large Igneous Province; Mar. Geophys. Res. 20 273-291.

Torsvik T H, Tucker R D, Ashwal L D, Eide E A, Rakotosolofo N A and Dewit M J 1998 Late Cretaceous magmatism in Madagascar: Paleomagnetic evidence for a stationary Marion hotspot; Earth. Planet. Sci. Lett. 164 221-232.

Tucholke B E, Houtz R E and Berrett D M 1981 Continental crust beneath the Agulhas Plateau, southwest Indian Ocean; J. Geophys. Res. 86 3791-3806.

Verzhbitsky E V 2003 Geothermal regime and genesis of the Ninety-East and Chagos-Laccadive Ridges; J. Geodynam. 35 289-302.

Weser O E 1974 Sedimentological aspects of strata encountered on Leg 23 in the northern Arabian Sea; In: Initial Reports of the Deep Sea Drilling Project (eds) Whitmarsh R B, Weser O E, Ross D A and others (Washington: US Goverment Printing Office) 23 $503-519$.

White R S and McKenzie D 1989 Magmatism at rift zones: The generation of volcanic continental margins and flood basalts; J. Geophys. Res. 94 7685-7729.

Whitmarsh et al 1974 Site 219; In: Initial Reports of the Deep Sea Drilling Project (eds) Whitmarsh R B, Weser O E, Ross D A and others (Washington: US Government Printing Office) 23 35-115.

White R S et al 1987 Hatton Bank (northwest UK) continental margin structure; Geophys. J. R. Astron. Soc. 89 265-267.

Yatheesh V, Bhattacharya G C and Dyment J 2009 Early oceanic opening off western India-Pakistan margin: The Gop Basin revisited; Earth. Planet. Sci. Lett. 284 399-408. 